\title{
Development of GHG Emission Factors for the Life Cycle of the Animal Manure Treatment Systems
}

\author{
Yoosung Park ${ }^{1 \odot} \cdot$ Sung-Mo Yeon $^{1 \odot} \cdot$ Kyu-Hyun Park ${ }^{2,+}$ \\ ${ }^{1}$ Humanitarian Ideal Pathway Co., LTD. \\ ${ }^{2}$ Department of Animal Industry Convergence, Kangwon National University
}

(Received October 13, 2020; Revised November 24, 2020; Accepted November 26, 2020)

Objectives: A whole process greenhouse gas emission factor was developed considering the direct greenhouse gas emission from the decomposition of livestock manure provided by the IPCC guidelines and the energy consumption of manure management systems.

Methods: Greenhouse gas generated by animal manure management is divided into direct greenhouse gas emission by decomposition of manure and greenhouse gas effect in the entire process due to energy use by operating manure management systems. By obtaining and summing them, the whole process greenhouse gas emission factor for the livestock manure treatment system was calculated.

Results and Discussion: Among the pig manure management systems, the greenhouse gas emission factors for composting, purification and liquefaction were calculated as $128 \mathrm{kgCO}_{2}$-eq./ton, $123 \mathrm{kgCO}_{2}$-eq./ton, $119 \mathrm{kgCO}$-eq./ton, respectively. It was analyzed that $20.7 \%$ to $24.1 \%$ of greenhouse gas emissions generated in the process of managing manure were due to electricity use. As a result of analyzing the change in the emission factor according to the change in GHG emissions of the national electric power according to the 8th Basic Plan for Electricity Supply and Demand, a change in emission of about $6 \%$ was confirmed. Based on the results of this study and analysis of direct GHG emissions from manure management in three major Western European countries, France, Germany, and the Netherlands, based on the manure management emission factor in 2017 , GHG emissions of $48.9 \%$ to $70 \%$ compared to this study in all countries.

Conclusions: In the greenhouse gas emission factor for the pig manure management system, the greenhouse gas emission from energy used in the manure management system operation represents a contribution of more than $20 \%$, so improvement of energy efficiency of the manure management system in the future can contribute to the reduction of greenhouse gas emission. As the GHG emissions of the pig manure management system are expected to change substantially according to the change in the power grid composition ratio according to the 8th Basic Plan for Electricity Supply and Demand, it is necessary to study the application plan in preparation for the implementation of product environmental footprint certification for livestock products in the future. As a result of comparing direct GHG emissions by manure management with major Western European countries, the difference in emissions was found to be large, suggesting the need to develop a Tier 2 emission factor suitable for the situation in Korea.

Keywords: GHG Factor for Manure Management System, Methane from Manure Management, Nitrous Oxide from Manure Management, Electricity Grid, Tier 2 Emission Factor

The Korean text of this paper can be translated into multiple languages on the website of http://jksee.or.kr through Google Translator. 


\title{
연구논문
}

\section{가축 분뇨처리 방법별 전과정 온실가스 배출계수 개발 연구}

\author{
박유성 $^{1 \odot \cdot} \cdot$ 연성모 $^{1 \odot} \cdot$ 박규현 $^{2,+\odot ~}$
}

'(주)에이치아이피

2강원대학교 동물산업융합학과

목적 : IPCC 가이드라인에서 제공하는 가축분뇨의 분해에 의한 직접 온실가스 배출량과 더불어 분뇨처리 시설 운 영에 따른 에너지 사용량을 고려한 전과정 온실가스 배출계수를 개발하였다.

방법: 가축 분뇨처리에 의해 발생하는 온실가스는 분뇨의 분해에 의해 직접 온실가스 배출과 분뇨처리 시설을 운 영함에 따라 발생하는 에너지 사용에 의한 전과정 온실가스 영향으로 구분되며 이 두 가지 측면에 대한 온실가스 배출량을 구하여 이를 합산함으로써 가축 분뇨처리 시스템에 대한 전과정 온실가스 배출계수를 산출하였다.

결과 및 토의: 돼지 분뇨처리 시스템 중 퇴비화, 정화처리, 액비화에 대한 온실가스 배출계수는 각각 $128 \mathrm{kgCO}_{2}$-eq./ton, $123 \mathrm{kgCO}_{2}$-eq./ton, $119 \mathrm{kgCO}_{2}$-eq./ton으로 산출되었다. 분뇨를 처리하는 과정에서 발생하는 온실가스 배출량의 $20.7 \%$ $\sim 24.1 \%$ 는 전력사용에 의한 것으로 분석되었다. 이에 제8차 전력수급 기본계획에 따른 국가전력의 온실가스 배출량 변화에 따라 배출계수의 변화를 분석한 결과 약 $6 \%$ 의 배출량 변화가 확인되었다. 끝으로 이번 연구 결과와 주요 서유럽국가인 프랑스, 독일, 네덜란드 3 개국의 분뇨처리 직접 온실가스 배출량을 분석한 결과, 2017년 분뇨처리 배출계 수 기준 모든 국가에서 이번 연구 대비 $48.9 \%$ 70\% 수준의 온실가스 배출량을 보이고 있다.

결론 : 돼지 분뇨처리 시스템에 대한 온실가스 배출계수에서 분뇨처리 시스템 운영에 사용되는 에너지에 의한 온실 가스 배출량은 $20 \%$ 이상의 기여도를 나타내고 있어 향후 분뇨처리 시스템의 에너지 효율 개선이 온실가스 배출량 저감에 기여할 수 있을 것으로 판단된다. 제 8 차 전력수급 기본계획에 따른 전력망 구성 비율 변화에 따라 돼지 분 뇨처리 시스템의 온실가스 배출량의 실질적인 변화가 예상되기 때문에 향후 축산물에 대한 제품환경발자국 인증 시행을 대비하여 적용 방안에 대한 연구가 필요할 것으로 사료된다. 끝으로 주요 서유럽 국가와의 분뇨처리에 의 한 직접 온실가스 배출량을 비교한 결과 배출량의 차이가 큰 것으로 나타났으며 우리나라 실정에 적합한 Tier 2 배출계수의 개발이 필요함을 시사한다.

주제어: 분뇨처리 온실가스 배출계수, 분뇨처리 메탄, 분뇨처리 아산화질소, 전력망, Tier 2 배출계수

\section{1. 서 론}

우리나라는 현재 운영되고 있는 축산분뇨 처리방법의 비 율과 분뇨발생량 및 처리량에 대하여 통계데이터를 구축하 여 관리하고 있다. 하지만 분뇨처리를 위해 운영되고 있는 시설에 의한 에너지 사용량은 별도로 관리하지 않고 있어 통계자료만을 통해 분뇨처리에 의해 발생되는 전과정 온실 가스 배출량을 산출하는 것은 어려운 실정이다.

기후 변화에 관한 정부간 패널(Intergovernmental Panel on Climate Change, 이하 IPCC) 가이드라인은 가축 사육과정에 서 발생하는 장내발효 및 분뇨처리로 인해 발생하는 온실가 스 배출량을 산출하는 방법을 기술하고 있다. 축산업과 관 련하여 IPCC 가이드라인에서 다루는 온실가스 배출량은 가
축 체내의 장내발효에 의해 직접 발생되는 메탄과 분뇨처리 과정에서 분뇨가 분해되며 직접 발생하는 메탄과 아산화질 소, 질소산화물에 의해 간접적으로 발생하는 아산화질소에 의한 온실가스에 국한되어있다. ${ }^{1)}$ 이에 가축 및 축산물의 전 과정에서 발생하는 온실가스 영향을 비롯한 환경영향을 파 악하기 위해 가축 및 축산물에 대한 전과정평가 연구가 활 발히 진행되고 있으며 젖소와 육우 이외에 돼지에 대한 연 구도 다수 진행되고 있다.-4) 돼지에 대한 전과정평가 연구 를 살펴보면 대체로 연구 대상 농장의 사료 급여량, 에너지 사용량 및 분뇨처리 과정을 조사하고 실제 현장데이터를 수 집함으로써 분뇨처리를 포함한 사육에 필요한 시설을 운영 하는데 사용되는 에너지 및 기타 투입물질에 대한 데이터를 수집하여 결과를 도출하고 있다. ${ }^{5-14)}$ 
그러나 축산물에 대한 제품환경발자국(Product Environmental Footprint, $\mathrm{PEF}$ ) 인증을 추진할 때 사료 급여량, 축사의 전력 사용량 등과 같이 농장에서 직접 관리하는 데이터 이외의 공동 분뇨처리 시설 운영에 대한 데이터와 직접 발생되는 온실가스 배출량 산출을 위한 세부 데이터까지 수집하는 것은 현실적으 로 불가능하다. 따라서 제품환경발자국 인증 제도가 정착되기 위해서는 산업군에서 공통적으로 적용되는 공정에 대한 전과 정목록 데이터베이스(이하 LCI 데이터베이스)를 구축하여 데 이터 수집을 위해 소요되는 시간과 비용을 절감해야만 제도가 원활히 운영될 수 있다. 일본에서는 분뇨처리시설의 환경영향 특징 비교를 목적으로 시설이용사례 및 시설 설계치를 통해 비육돈에 대한 분뇨처리시설 도입단계와 운영단계를 고려한 LCI 분석 연구를 진행하였다. ${ }^{9)}$

현재 우리나라에서는 농업기술실용화재단에서 운영하는 저탄소 농축산물 인증제도가 시행되고 있으나 축산물에 대 한 공식 인증기준을 현재 개발하고 있으며, 인증제도에 사 용할 수 있는 LCI 데이터베이스도 부족한 실정이다. 특히 분뇨처리 방법과 설비에 따른 온실가스 배출계수가 없어 분 뇨처리 시스템의 개선에 의한 저탄소 농축산물 인증제도 기 준이 마련되어도 바로 시행하는데 애로사항이 발생할 수 있 는 실정이다.

이번 연구에서는 IPCC 가이드라인에서 제공하는 가축분 뇨의 분해에 의한 직·간접 온실가스 배출량과 더불어 분뇨 처리 시설 운영에 따른 에너지 사용량을 고려한 전과정 온 실가스 배출계수를 개발하였다. 아직 공식적으로 인정된 분 뇨처리에 대한 IPCC Tier 2 국내 배출계수는 없기 때문에 분뇨의 분해에 의한 직·간접 온실가스 배출량은 IPCC Tier 1 배출계수를 활용하여 산출하였다. 아울러 우리나라와 유 사한 축산업 특성을 가지고 있는 서유럽의 분뇨처리에 의한 온실가스 IPCC Tier 2 배출계수를 적용할 경우, 전과정 온 실가스 배출계수의 변화를 살펴봄으로써 국내분뇨처리에 의한 온실가스 IPCC Tier 2 계수의 개발 필요성에 대한 검 토도 진행하였다.

\section{2. 재료 및 방법}

가축 분뇨처리 방법에 대한 전과정 온실가스 배출계수는 분뇨의 분해에 의해 발생하는 직접 온실가스 배출과 분뇨처 리 시설을 운영함에 따라 발생하는 에너지 사용에 의한 전 과정 온실가스 영향의 두 가지 측면으로 구분이 된다. 이번 연구에서는 이 두 가지 측면에 대한 온실가스 배출량을 구 하여 이를 통합하는 방식으로 가축 분뇨처리에 의한 전과정 온실가스 배출계수를 산출하였다.

\section{1. 기능 및 기능단위}

이번 연구 대상 시스템은 돼지 사육에 적용되는 분뇨처리

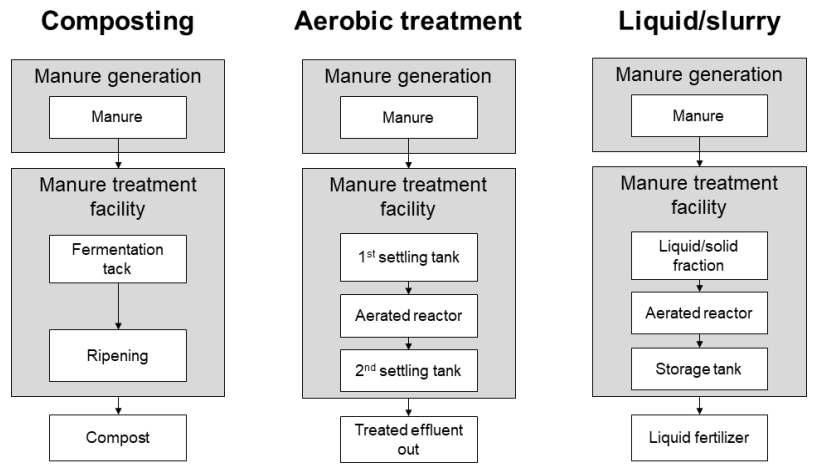

Fig. 1. System boundary of the manure treatment systems.

시스템이며 돼지로부터 발생한 분뇨의 처리를 기능으로 하 며 기능단위는 1 ton의 분뇨처리로 하였다.

\section{2. 시스템 경계}

이번 연구는 돼지의 분뇨 배설부터 분뇨처리시설에서 분 뇨처리가 완료되는 시점까지로 설정하였다. IPCC 가이드라 인 2006에 따라 분뇨처리과정에서 직접적으로 배출되는 메 탄과 아산화질소를 포함하였다. ${ }^{1)}$ 또한 분뇨처리시설에서 사용하는 에너지의 생산과 소비에 의한 온실가스 배출량을 포함하였으며 분뇨처리시설에서 사용되는 화학물질, 미생 물제 등과 같은 자재는 시스템 경계에서 제외하였다(Fig. 1 참조). 분뇨처리 시설에 사용되는 화학물질과 미생물제 등 의 자제를 시스템 경계에서 제외한 이유는 연구 대상 설비 중 퇴비화와 액비화 설비에는 별도의 투입물이 없으며 정화 처리에는 소석회, 황산알루미늄 및 폴리머 등이 투입되나 분뇨 10 톤을 처리하는데 약 $2 \mathrm{~kg}$ 정도의 양만 투입되어 약 $0.02 \%$ 정도의 비중만 차지하여 제외하였다.

\section{3. 데이터 수집 및 온실가스 배출계수 개발}

이번 연구의 가축분뇨 처리시설의 운영에 필요한 에너지 데이터는 농림축산식품부와 축산환경관리원에서 공동으로 발간한 가축분뇨 처리시설 및 관련기술 평가의 가축분뇨처 리 설비 중 3 가지 시스템 분류-퇴비화(A), 정화처리(B), 액 비화 $(\mathrm{C})$ - 에 포함되는 설비에 대한 데이터의 평균값을 활용 하였다. ${ }^{15-18)}$ 퇴비화 공정은 발생한 가축분뇨를 미생물을 이 용하여 분해시키는 방법으로 가축분뇨가 미생물에 의해 퇴 비화 되면 대부분의 유기물은 물, 이산화탄소, 암모니아 등 의 무기물로 전환되어 토양에 시비할 수 있는 퇴비로 가공 하는 공정이다. 정화처리는 물리·화학적 또는 생물학적 수 처리 방법으로 분뇨를 분해하여 일정 수준의 수질로 정화처 리하여 방류하는 시스템을 말한다. 액비화 공정은 수분함량 이 $85 \%$ 이상인 액상분뇨를 처리하는 공정으로써 호기성소 화를 통해 액상형 비료를 만드는 공정을 말한다.

퇴비화 및 액비화의 경우, 처리과정에서 온도와 습도를 
Table 1. Manure management methane emission factor for pig of Korea.

\begin{tabular}{|c|c|c|c|c|c|}
\hline District & $\begin{array}{l}\text { Annual average } \\
\text { temperature }\left({ }^{\circ} \mathrm{C}\right)\end{array}$ & $\begin{array}{l}\text { Emission factor by average } \\
\text { annual temperature } \\
\text { (kgCH}{ }_{4} / \text { head/year) }\end{array}$ & Number of head & $\begin{array}{l}\text { Ratio for } \\
\text { head }(\%)\end{array}$ & $\begin{array}{l}\text { Weighted average } \\
\text { emission factor } \\
\text { (kgCH} / \text { head/year) }\end{array}$ \\
\hline Seoul & 13 & 7 & 2,445 & 0.03 & 0.002 \\
\hline Busan & 15 & 9 & 9,069 & 0.09 & 0.008 \\
\hline Daegu & 15 & 9 & 15,448 & 0.16 & 0.014 \\
\hline Incheon & 12 & 7 & 33,246 & 0.34 & 0.024 \\
\hline Gwangju & 14 & 8 & 6,864 & 0.07 & 0.006 \\
\hline Daejeon & 13 & 7 & 1,281 & 0.01 & 0.001 \\
\hline Ulsan & 14 & 8 & 34,084 & 0.35 & 0.028 \\
\hline Gyeonggi-do & 12 & 7 & $1,670,695$ & 17.25 & 1.208 \\
\hline Gangwon-do & 11 & 6 & 395,360 & 4.08 & 0.245 \\
\hline Chungcheongbuk-do & 12 & 7 & 560,847 & 5.79 & 0.405 \\
\hline Chungcheongnam-do & 12 & 7 & $1,956,803$ & 20.21 & 1.415 \\
\hline Jeollabuk-do & 13 & 7 & $1,179,332$ & 12.18 & 0.853 \\
\hline Jeollanam-do & 14 & 8 & 977,516 & 10.10 & 0.808 \\
\hline Gyeongsangbuk-do & 13 & 7 & $1,181,934$ & 12.21 & 0.855 \\
\hline Gyeongsangnam-do & 14 & 8 & $1,124,493$ & 11.61 & 0.929 \\
\hline Jeju & 16 & 9 & 533,052 & 5.51 & 0.496 \\
\hline Total/average & - & - & $9,682,471$ & 100.00 & 7.295 \\
\hline
\end{tabular}

유지해야하기 때문에 전력을 사용하며, 정화처리의 경우, 교반과 폭기 과정에서 주로 전력을 소비한다. 전력 사용에 의한 온실가스 배출량은 전력에 대한 전과정평가를 기반으 로 하는 환경성적표지 제도에서 사용하는 전력에 대한 온실 가스 배출계수인 $0.495 \mathrm{kgCO}_{2}-\mathrm{eq} / \mathrm{kWh}$ 와 설비별로 사용되 는 전력 소비량을 곱하여 산출하였다.

우리나라 국가 온실가스 인벤토리 산출을 위한 돼지 분뇨 처리에 대한 메탄 및 아산화질소 배출계수는 IPCC 가이드 라인(1996)의 서유럽의 배출계수를 사용하고 있다. ${ }^{19)}$ 이에 이번 연구에서는 향후 IPCC 가이드라인(2006) 적용에 대비 하여 IPCC 가이드라인(2006)에서 제시하고 있는 서유럽의 돼지 분뇨처리에 의한 메탄 및 아산화질소 Tier 1 배출계수 를 활용하였다. 돼지 분뇨처리에 의한 메탄 배출계수는 지 역과 연평균 기온별 메탄배출량을 제시하고 있다. 우리나라 의 경우, 2009년 2018년 사이의 각 시·도별 연평균기온은 $11 \sim 16^{\circ} \mathrm{C}$ 사이에 분포하고 있다. ${ }^{20)}$ 이에 국내 돼지 분뇨처 리에 의한 매탄 배출계수의 평균을 각 연평균기온에 해당하 는 시·도의 2009년 2018년의 돼지 사육 두수 통계자료를 이용하여 가중평균값을 구하여 이번 연구에 적용하였다. ${ }^{21)}$ 예를 들어 행정구역상 부산에서 사육되는 돼지는 전체 사육 두수의 $0.09 \%$ 에 해당한다. 부산의 연평균 기온은 $15^{\circ} \mathrm{C}$ 로써 $\mathrm{IPCC}$ 가이드라인에서 제공하는 분뇨처리에 의한 Tier 1 메탄 배출계수 표에 따르면 $9 \mathrm{kgCO}_{2}$-eq/head/year에 해당한 다. 전체 사육두수 비율과 부산 지역의 분뇨처리에 의한 Tier 1 메탄 배출계수인 $9 \mathrm{kgCO}_{2}$-eq/head/year을 곱하면 0.008 $\mathrm{kgCO}_{2}$-eq/head/year가 된다. 이를 모든 지역별 배출계수와
사육두수 비율을 곱하여 산출된 배출계수를 모두 더하면 우 리나라 평균 분뇨처리에 의한 Tier 1 메탄 배출계수가 산출 되며 그 결과를 Table 1에 기재하였다.

IPCC 가이드라인의 배출계수는 돼지 1마리당 연간 배출 하는 메탄과 아산화질소에 대한 배출계수를 제시하고 있기 때문에 이번 연구의 기능단위인 1 ton의 분뇨처리와 일치하 도록 조정할 필요가 있다. 이에 환경부에서 고시한 돼지 한 마리당 일간 분뇨 발생량인 $5.1 \mathrm{~kg} / \mathrm{head} \cdot \mathrm{day}$ 를 활용하여 1 ton의 돼지분뇨 처리 시 발생하는 메탄 및 아산화질소의 양을 산출하였다. ${ }^{22)} \mathrm{IPCC}$ 가이드라인에서 제공하는 돼지분 뇨처리 시 발생하는 메탄 및 아산화질소에 대한 배출계수는 돼지 1 마리에 의해 1 년간 배출하는 분뇨처리 메탄 및 아산 화질소에 대한 배출계수이기 때문에 이를 분뇨 1 톤당 배출 량으로 환산하기 위하여 환경부 고시에 제시된 돼지 1마리 가 발생시키는 일간 분뇨처리량으로 나누어 분뇨 1 톤 처리 당 메탄 및 아산화질소 배출계수를 산출하였다.

\section{3. 결과 및 고찰}

\section{1. 돼지 분뇨 처리 온실가스 배출계수 결과}

돼지 분뇨처리과정에서 직접 배출되는 메탄과 아산화질 소의 양은 분뇨처리 시스템에 따라 약간의 차이를 나타내 고 있다. IPCC 2006에서는 분뇨처리 시설을 세부적으로 구 분하고 있으며 퇴비화(A) 시스템은 Composting-In-Vessel, 정화처리(B) 시스템은 Aerobic treatment (Forced aeration systems) 그리고 액비화(C) 시스템은 Liquid/Slurry (With 
Table 2. Direct greenhouse gas (GHG) emissions from animal manure treatment systems.

\begin{tabular}{|c|c|c|c|c|}
\hline \multicolumn{2}{|c|}{ Contents } & $A^{*}$ & $B^{* *}$ & $C^{* * *}$ \\
\hline \multirow{2}{*}{ Manure generation of pig } & $\mathrm{kg} / \mathrm{head} \cdot$ day & 5.1 & 5.1 & 5.1 \\
\hline & ton/head·year & 1.8615 & 1.8615 & 1.8615 \\
\hline \multirow{2}{*}{ Methane } & $\mathrm{kgCH}_{4} /$ head/year & 7.295 & 7.295 & 7.295 \\
\hline & $\mathrm{kgCH}_{4} /$ ton & 3.919 & 3.919 & 3.919 \\
\hline \multirow{2}{*}{ Nitrous oxide } & $\mathrm{kgN}_{2} \mathrm{O} /$ head/year & 0.088 & 0.073 & 0.073 \\
\hline & $\mathrm{kgN}_{2} \mathrm{O} /$ ton & 0.047 & 0.039 & 0.039 \\
\hline \multicolumn{2}{|c|}{$\mathrm{CO}_{2}$-eq (kg/ton) } & 96.867 & 94.387 & 94.387 \\
\hline
\end{tabular}

System categories according to IPCC (2006)

${ }^{*}$ Composting - In-Vessel

${ }^{* *}$ Aerobic treatment (Forced aeration systems)

${ }^{* * *}$ Liquid/Slurry (With natural crust cover)

Table 3. GHG emissions due to the use of electricity during animal manure treatment.

\begin{tabular}{cccc} 
Contents & $\mathrm{A}^{*}$ & $\mathrm{~B}^{* *}$ & $\mathrm{C}^{* * *}$ \\
$\mathrm{GHG}$ emissions per $\mathrm{kWh}(\mathrm{kgCO}-\mathrm{eq} / \mathrm{kWh})$ & $4.95 \mathrm{E}-01$ & $4.95 \mathrm{E}-01$ & $4.95 \mathrm{E}-01$ \\
\hline The use of electricity $(\mathrm{kWh} / \mathrm{ton})$ & $6.22 \mathrm{E}+01$ & $5.83 \mathrm{E}+01$ & $4.97 \mathrm{E}+01$ \\
\hline GHG emissions $(\mathrm{kgCO}$-eq/ton) & $3.08 \mathrm{E}+01$ & $2.89 \mathrm{E}+01$ & $2.46 \mathrm{E}+01$ \\
\hline
\end{tabular}

Table 4. Total GHG emissions from animal manure treatment systems.

\begin{tabular}{cccc} 
Source & $\mathrm{A}^{*}$ & $\mathrm{~B}^{* *}$ & $\mathrm{C}^{* * *}$ \\
Manure treatment $\left(\mathrm{kgCO}_{2}\right.$-eq/ton) & $9.69 \mathrm{E}+01$ & $9.44 \mathrm{E}+01$ & $9.44 \mathrm{E}+01$ \\
\hline Electricity $\left(\mathrm{kgCO}_{2}\right.$-eq/ton) & $3.08 \mathrm{E}+01$ & $2.89 \mathrm{E}+01$ & $2.46 \mathrm{E}+01$ \\
\hline Total $\left(\mathrm{kgCO}_{2}\right.$-eq/ton) & $1.28 \mathrm{E}+02$ & $1.23 \mathrm{E}+02$ & $1.19 \mathrm{E}+02$ \\
\hline GHG emission contribution of electricity & $24.1 \%$ & $23.5 \%$ & $20.7 \%$ \\
\hline
\end{tabular}

natural crust cover)을 이용하는 것으로 설정하고 아산화질 소 배출량을 산출하였다. 분뇨처리에 의한 메탄 배출량은 앞서 Table1과 같이 산출된 Tier 1 배출계수를 사용하여 분 뇨처리 시스템별로 메탄배출량의 차이가 없는 것으로 산출 되었다(Table 2 참조).

전력 사용에 의한 온실가스 배출량은 분뇨처리 시스템에 따라 다르게 나타났다. 분뇨처리 시스템마다 분뇨를 처리하 는 방법에 차이가 있어 단위 중량의 분뇨 처리과정에서 소비 되는 전력사용 원단위의 차이에 의한 것으로 나타났다. 퇴비 화(A), 정화처리(B), 액비화 $(\mathrm{C})$ 시스템의 1 ton의 분뇨처리를 위한 전력 소비량은 각각 $62.20 \mathrm{kWh}, 58.29 \mathrm{kWh}, 49.70 \mathrm{kWh}$ 로 나타났으며 분뇨처리 설비별 전력 사용에 의한 온실가스 배출량은 Table 3에 기재하였다.

최종 결과인 분뇨처리 시스템별 온실가스 배출량은 Table 4에 기재하였다. 돼지분뇨 처리과정에서 가장 많은 온실가 스를 배출량을 나타내는 시스템은 퇴비화(A) 시스템으로 $127.553 \mathrm{~kg} \mathrm{CO}$-eq/ton으로 산출되었다. 연구 대상이 된 세 가지 분뇨처리 시스템에서 분뇨의 분해에 의해 직접 배출되 는 온실가스 배출량은 $2.48 \mathrm{~kg} \mathrm{CO}$-eq/ton의 차이가 난다. 하지만 분뇨처리 시스템 운전에 사용되는 전력에 의한 온실
가스 배출량은 최대 $6.187 \mathrm{~kg} \mathrm{CO}$-eq/ton의 차이가 발생하 며 이는 직접 배출되는 온실가스 배출량 차이의 2.49 배에 달한다. 또한 1 ton의 분뇨를 처리하는 과정에서 발생하는 온실가스 배출량의 $20.7 \% \sim 24.1 \%$ 는 전력사용에 의한 것으 로 분뇨처리 시스템의 전력사용량을 줄이는 것이 온실가스 배출량 감축을 위한 주요한 인자로 작용할 것으로 사료된다.

\section{2. 전력망 구성 변화에 따른 온실가스 배출량 추이}

제8차 전력수급 기본계획에 따르면 우리나라는 정격기준 전원구성 전망의 2017년 기준 $67.0 \%$ 에 달하는 석탄, $\mathrm{LNG}$, 석유 등 화석연료의 발전비중을 2031년까지 $50.9 \%$ 로, $19.3 \%$ 에 해당하는 원자력을 $11.7 \%$ 까지 줄이며 같은 기간 신재생 에너지 비율을 $9.7 \%$ 에서 $33.6 \%$ 까지 늘리려는 계획을 가지 고 있다. ${ }^{23)}$ 현재 국가에서 개발한 전력에 대한 온실가스 배 출계수는 $0.495 \mathrm{kgCO}_{2}$-eq/ $/ \mathrm{kWh}$ 를 사용하고 있으나 이는 1998년도 기준의 배출계수이며 2017년 기준의 전력망 비율 을 적용할 경우, $0.631 \mathrm{kgCO}_{2}-\mathrm{eq} / \mathrm{kWh}$ 의 배출계수를 적용하 는 것이 적합한 실정이다. 제 8차 전력수급계획에 따라 전력 망의 구성이 Table5에 기재된 비율에 따라 전환된다면 2031 년 우리나라의 전력은 $0.509 \mathrm{kgCO}_{2}-\mathrm{eq} / \mathrm{kWh}$ 의 온실가스 배 
Table 5. Prospect of electricity grid according to the 8th basic electric power supply and demand plan.

\begin{tabular}{|c|c|c|c|c|c|c|}
\hline Source & Unit & 2017 & 2020 & 2026 & 2030 & 2031 \\
\hline Coal & $\%$ & 32.90 & 31.50 & 29.10 & 25.90 & 25.60 \\
\hline Oil & $\%$ & 3.50 & 2.00 & 0.90 & 0.80 & 0.80 \\
\hline LNG & $\%$ & 31.90 & 29.50 & 29.00 & 27.30 & 27.20 \\
\hline Biogas & $\%$ & 2.50 & 3.40 & 4.10 & 4.30 & 4.30 \\
\hline Waste incineration & $\%$ & 2.80 & 2.80 & 2.80 & 2.70 & 2.70 \\
\hline Nuclear & $\%$ & 19.30 & 19.30 & 15.50 & 11.70 & 11.70 \\
\hline Hydropower & $\%$ & 0.80 & 0.90 & 1.00 & 1.10 & 1.10 \\
\hline photovoltaic & $\%$ & 1.70 & 4.50 & 7.80 & 11.30 & 11.40 \\
\hline Wind power & $\%$ & 0.60 & 2.70 & 6.70 & 11.40 & 11.40 \\
\hline Hydropower, pumped storage & $\%$ & 4.00 & 3.30 & 3.10 & 3.50 & 3.80 \\
\hline Total & $\%$ & 100.00 & 100.00 & 100.00 & 100.00 & 100.00 \\
\hline
\end{tabular}

Table 6. GHG emission of $1 \mathrm{kWh}$ electricity according to the 8th basic electric power supply and demand plan.

\begin{tabular}{ccccccc} 
Source & Unit & 2017 & 2020 & 2026 & 2030 & 2031 \\
Coal & $\mathrm{kgCO}_{2}$-eq & $3.55 \mathrm{E}-01$ & $3.40 \mathrm{E}-01$ & $3.14 \mathrm{E}-01$ & $2.79 \mathrm{E}-01$ & $2.77 \mathrm{E}-01$ \\
\hline Oil & $\mathrm{kgCO}_{2}$-eq & $3.10 \mathrm{E}-02$ & $1.77 \mathrm{E}-02$ & $7.97 \mathrm{E}-03$ & $7.08 \mathrm{E}-03$ & $7.08 \mathrm{E}-03$ \\
\hline LNG & $\mathrm{kgCO}_{2}$-eq & $2.05 \mathrm{E}-01$ & $1.90 \mathrm{E}-01$ & $1.86 \mathrm{E}-01$ & $1.75 \mathrm{E}-01$ & $1.75 \mathrm{E}-01$ \\
\hline Biogas & $\mathrm{kgCO}_{2}$-eq & $5.97 \mathrm{E}-03$ & $8.12 \mathrm{E}-03$ & $9.79 \mathrm{E}-03$ & $1.03 \mathrm{E}-02$ & $1.03 \mathrm{E}-02$ \\
\hline Waste incineration & $\mathrm{kgCO}_{2}$-eq & - & - & - & - & - \\
\hline Nuclear & $\mathrm{kgCO}_{2}$-eq & $1.51 \mathrm{E}-03$ & $1.51 \mathrm{E}-03$ & $1.21 \mathrm{E}-03$ & $9.15 \mathrm{E}-04$ & $9.15 \mathrm{E}-04$ \\
\hline Hydropower & $\mathrm{kgCO}_{2}$-eq & $2.96 \mathrm{E}-05$ & $3.33 \mathrm{E}-05$ & $3.70 \mathrm{E}-05$ & $4.07 \mathrm{E}-05$ & $4.07 \mathrm{E}-05$ \\
\hline photovoltaic & $\mathrm{kgCO}_{2}$-eq & $1.19 \mathrm{E}-03$ & $3.16 \mathrm{E}-03$ & $5.48 \mathrm{E}-03$ & $7.93 \mathrm{E}-03$ & $8.00 \mathrm{E}-03$ \\
\hline Wind power & $\mathrm{kgCO}_{2}$-eq & $6.74 \mathrm{E}-05$ & $3.03 \mathrm{E}-04$ & $7.53 \mathrm{E}-04$ & $1.28 \mathrm{E}-03$ & $1.28 \mathrm{E}-03$ \\
\hline Hydropower, pumped storage & $\mathrm{kgCO}_{2}$-eq & $3.14 \mathrm{E}-02$ & $2.59 \mathrm{E}-02$ & $2.43 \mathrm{E}-02$ & $2.74 \mathrm{E}-02$ & $2.98 \mathrm{E}-02$ \\
\hline Total & $\mathrm{kgCO}_{2}$-eq & $6.31 \mathrm{E}-01$ & $5.86 \mathrm{E}-01$ & $5.50 \mathrm{E}-01$ & $5.10 \mathrm{E}-01$ & $5.09 \mathrm{E}-01$ \\
\hline
\end{tabular}

Table 7. Total GHG emission from the manure treatment system according to changes in the electricity grid by year (kgCO - -eq/ton).

\begin{tabular}{cccccccc} 
Contents & This study & 2017 & 2020 & 2026 & 2030 & 2031 \\
$\mathrm{~A}^{*}$ & $1.28 \mathrm{E}+02$ & $1.36 \mathrm{E}+02$ & $1.33 \mathrm{E}+02$ & $1.31 \mathrm{E}+02$ & $1.29 \mathrm{E}+02$ & $1.29 \mathrm{E}+02$ \\
\hline $\mathrm{B}^{* *}$ & $1.23 \mathrm{E}+02$ & $1.31 \mathrm{E}+02$ & $1.29 \mathrm{E}+02$ & $1.26 \mathrm{E}+02$ & $1.24 \mathrm{E}+02$ & $1.24 \mathrm{E}+02$ \\
\hline $\mathrm{C}^{* *}$ & $1.19 \mathrm{E}+02$ & $1.26 \mathrm{E}+02$ & $1.23 \mathrm{E}+02$ & $1.22 \mathrm{E}+02$ & $1.20 \mathrm{E}+02$ & $1.20 \mathrm{E}+02$ \\
\hline
\end{tabular}

출량을 나타내게 된다(Table 6 참조).

주요 연도별 전력의 온실가스 배출량 변화에 따른 돼지 분뇨처리 시스템의 온실가스 배출량은 2017년 전력망 기준 대비 2031년에는 분뇨처리 시스템 별로 약 $6 \%$ 의 온실가스 배출량이 저감되는 것으로 나타났다(Table 7 참조).

\section{3. 분뇨처리에 대한 IPCC Tier 2 배출계수 적용 시 온실가 스 배출량 변화}

우리나라의 국가온실가스인벤토리보고서는 가축의 분뇨 처리에 의한 온실가스 배출계수로 IPCC (1996)의 Tier 1을 적용하고 있으며 돼지 분뇨 처리에 의한 메탄 배출계수는 $3 \mathrm{kgCH}_{4} / \mathrm{head} / \mathrm{year}$ 이며, 아산화질소 배출계수는 분뇨처리 시설을 액비화시설, 퇴비화시설, 기타시설로 분류하고 있
으며 각각 $0.02 \mathrm{kgN}_{2} \mathrm{O} / \mathrm{head} / \mathrm{year}, 0.4 \mathrm{kgN}_{2} \mathrm{O} / \mathrm{head} / \mathrm{year}, 0.1$ $\mathrm{kgN}_{2} \mathrm{O} / \mathrm{head} / \mathrm{year}$ 의 배출계수를 사용하고 있다. 돼지의 경우 특히 적용하고 있는 IPCC 기본값 배출계수는 서유럽 지역 의 계수를 활용하고 있으며 Table 8에는 주요 서유럽 국가 인 프랑스, 독일, 네덜란드에서 사용하고 있는 돼지 분뇨처 리에 의한 온실가스 배출계수를 기재하였다. ${ }^{24-26)}$ 이들 국가 는 자국의 상황에 적합한 Tier 2 배출계수를 개발하여 사용 하고 있다.

프랑스, 독일, 네덜란드의 돼지 분뇨처리에 대한 배출계수 와 이번 연구에서 사용된 돼지 분뇨처리 배출계수를 통해 산출한 온실가스 배출량은 Fig. 2와 같이 나타난다. 네덜란 드의 경우, 1990 년 기준 배출량은 $214 \mathrm{kgCO}_{2}$-eq/head/year 로 이번 연구에서 사용한 Liquid/Slurry 시스템의 배출계수 
Table 8. Direct GHG emissions factor from animal manure treatment systems by country.

\begin{tabular}{cccccccc}
\multirow{2}{*}{ Contents } & \multicolumn{2}{c}{ France } & \multicolumn{2}{c}{ Germany } & \multicolumn{2}{c}{ Netherlands } \\
\cline { 2 - 8 } & 1990 & 2017 & 1990 & 2017 & 1990 & 2017 \\
Methane $\left(\mathrm{kgCH}_{4} /\right.$ head/year) & $3.40 \mathrm{E}+00$ & $4.02 \mathrm{E}+00$ & $4.05 \mathrm{E}+00$ & $4.13 \mathrm{E}+00$ & $9.68 \mathrm{E}+00$ & $5.51 \mathrm{E}+00$ & $7.29 \mathrm{E}+00$ \\
\hline Nitrous Oxide $\left(\mathrm{kgN}_{2} \mathrm{O} /\right.$ head/year) & $1.24 \mathrm{E}-02$ & $4.50 \mathrm{E}-03$ & $4.77 \mathrm{E}-02$ & $7.23 \mathrm{E}-02$ & $3.38 \mathrm{E}-02$ & $2.44 \mathrm{E}-02$ & $7.30 \mathrm{E}-02$ \\
\hline
\end{tabular}

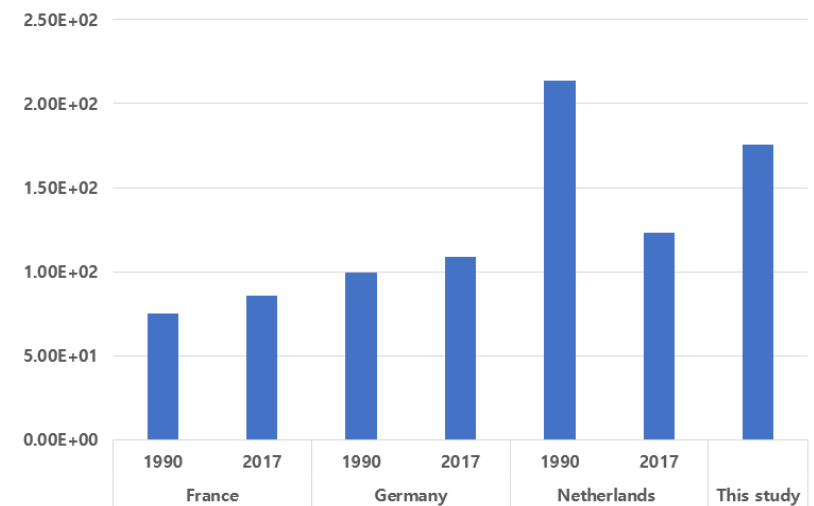

Fig. 2. Direct GHG emissions from animal manure treatment systems by country $\left(\mathrm{kgCO}_{2}\right.$-eq./head-year).

를 통해 산출한 온실가스 배출량보다 높게 나타났으나 2017 년 기준으로는 모든 국가에서 $48.9 \% \sim 70 \%$ 수준의 온실가 스 배출량을 보이고 있다.

\section{4. 결론}

이번 연구에서는 국내 축산물에 대한 탄소발자국 산정에 사용할 수 있는 돼지 분뇨처리 온실가스 배출계수를 개발하 였다. 돼지 분뇨처리 온실가스 배출계수는 분뇨처리 과정에 서 직접 배출되는 온실가스에 의한 영향과 분뇨처리 시스템 운영에 사용되는 에너지에 의한 온실가스 배출량을 정량화 하여 합산한 값을 사용하였으며 이번 연구의 결과는 다음과 같다.

1) 이번 연구의 연구 대상 돼지 분뇨처리 시스템은 퇴비 화, 정화처리, 액비화의 세가지 설비이며 각각의 온실 가스 배출계수는 $128 \mathrm{kgCO}_{2}$-eq./ton, $123 \mathrm{kgCO}_{2}$-eq./ton, 119 $\mathrm{kgCO}_{2}$-eq./ton으로 나타났다.

2) 분뇨처리에 대한 메탄 배출계수는 IPCC 가이드라인에 서 제공한 Tier 1 배출계수를 활용하였으며 Tier 1 메탄 배출 계수의 경우 분뇨처리 방법별로 구분되어 제공되지 않아 모 두 같은 배출계수를 적용하여 그 차이가 발생하지 않았다.

3) 현재 농촌진흥청에서 Tier 2 배출계수 개발을 위한 연 구과제를 수행 및 지원하고 있는 실정이며 Tier 2 배출계수 가 완성된 이후 재평가하는 과정이 필요할 것으로 사료된다.

4) 분뇨처리 과정에서 배출되는 메탄을 포집하여 에너지 로 활용하는 처리방법이 적용될 경우 온실가스 배출량 저감 측면에서 효과적인 대안이 될 것으로 예상되나 2017년 가
축분뇨 처리량 통계에 따르면 정화처리와 퇴비화, 액비화의 세 가지 처리방법이 차지하는 분뇨처리량 비중이 $77.0 \%$ 에 달하는 반면 바이오에너지 설비를 통해 처리되는 분뇨가 없 는 것으로 나타나고 있어 향후 이에 대한 연구와 실증이 진 행될 필요가 있다.

5) 전체 온실가스 배출계수에서 분뇨처리 시스템 운영에 사용되는 에너지에 의한 온실가스 배출량은 연구대상으로 선정한 세 가지 시스템 모두 $20 \%$ 이상의 기여도를 나타내 고 있으며 향후 분뇨처리 시스템의 효율 개선이 온실가스 배출량 저감에 기여할 수 있는 여지가 있을 것으로 판단할 수 있다.

6) 현재 우리나라 환경발자국 인증제도에서 사용하는 전 력에 대한 배출계수는 1998년 기준의 전력망 구성을 기준 으로 산출된 것으로 한국전력통계 기준으로 화력발전의 비 율이 약 $49.0 \%$ 이나 2017년 전력망 구성에서 화력발전의 비 율은 약 $61.0 \%$ 에 달하여 단위 전력당 온실가스 배출량은 증가해왔으나 이에 대한 갱신이 이루어지지 않았다.

7) 제 8 차 전력수급 기본계획에 따른 전력망 구성 비율 변화 에 따라 산출한 온실가스 배출계수를 적용해본 결과, 2017년 부터 화력발전 비중이 줄어들어 2031년 계획 기준 분뇨처리 시스템의 온실가스 배출계수는 약 $6 \%$ 의 차이가 발생하는 것으로 나타났다.

8) 이번 연구에서 개발한 배출계수는 기존 환경발자국 제 도에서 활용하는 전력의 온실가스 배출계수를 활용한 것이 나 전력망 구성에 따라 분뇨처리 시스템의 온실가스 배출량 에 차이가 발생하는 것을 확인하였고, 이에 향후 제품환경 발자국 인증에 대한 국가 간 상호인정 및 활용 측면에서 볼 때 국가 전력망 구성 비율의 변화에 따라 전력의 온실가스 배출계수가 적절하게 갱신될 수 있는 시스템 구축을 위한 연구가 필요할 것으로 사료된다.

9) 프랑스, 독일, 네덜란드의 국가 인벤토리 보고서를 확 인한 결과 분뇨처리에 의한 메탄 및 아산화질소에 대한 평 균 배출계수의 연도별 변화가 있으나 우리나라는 IPCC Tier 1 배출계수를 일괄 적용하고 있어 정확한 배출량 산출이 어렵 고 향후 제품환경발자국 인증의 상호인정 등에 저해를 받을 수 있어 이에 대한 연구도 함께 필요할 것으로 사료된다.

10) 끝으로 향후 축산물에 대한 탄소발자국 인증이 활성 화될 때를 대비하여 지역별, 분뇨처리 방법별 온실가스 배 출계수를 구축하여 탄소발자국 인증 결과의 고도화를 도모 하기 위한 기반 구축을 고민해 볼 필요가 있다. 


\section{Acknowledgement}

본 논문은 농촌진흥청 연구사업(세부과제번호: PJ01479703 2020)의 지원에 의해 이루어진 것입니다.

\section{References}

1. Intergovernmental Panel on Climate Change (IPCC), Emissions from Livestock and Manure Management, 2006 IPCC Guidelines for National Greenhouse Gas Inventories, IPCC(2006).

2. Food and Agriculture Organization of the United Nations (FAO), Greenhouse Gas Emissions from the Dairy Sector: A Life Cycle Assessment, Animal Production and Health Division, FAO(2010).

3. Food and Agriculture Organization of the United Nations (FAO), Tacking Climate Change through Livestock-A Global Assessment of Emissions and Mitigation Opportunities, Animal Production and Health Division, FAO(2013).

4. B. Notarnicola, R. Salonnmone, L. Petti, P. A. Renzulli, R. Roma, A. K. Cerutti, Life Cycle Assessment in the Agri-food Sector: Case Studies, Methodological Issues and Best Practices, Springer(2014).

5. C. Basset-Mens, H. Werf, Scenario-based environmental assessment of farming systems: the case of pig production in France, Agric. Ecosyst. Environ., 105(1-2), 127-144(2005).

6. C. Cederberg, A. Flysj, Environmental Assessment of Future Pig Farming System, Quantification of Three Scenarios from the FOOD 21 Synthesis Work, The Swedish Institute for Food and Biotechnology, Sweden(2004).

7. F. Boeri, Product Category Rules (PCR): Meat of mammals PCR 1202:11, Version 3.0, Prepared by Life Cycle Engineering, COOP Italia, Assocarni, Italy for: The International EPD System, Stockholm, Sweden(2012).

8. R. Dalgaard, N. Halberg, J. E. Hermansen, Danish Pork Production-An Environmental Assessment, DJF Animal Science No. 82(2007).

9. T. Hishinuma, Evaluation of environmental impact on livestock manure treatment and utilization system from life cycle approach, Journal of Rakuno Gakuen University Natural Science, 33(1), 19-71(2008).

10. C. Kingstone, J. M. Fry, S. Aumonier, Scoping Life Cycle Assessment of Pork Production, Environmental Resource Management, London, UK, pp. 1-33(2009).

11. G. M. Peters, H. V. Rowley, S. Wiedemann, R. Tucker, M. D. Short, M. Schulz, Red meat production in Australia: life cycle assessment and comparison with overseas studies, Environ. Sci. Technol., 44(4), 1327-1332(2010).

12. K. Reckmann, I. Traulsen, J. Krieter, Life cycle assessment of pork production: a data inventory for the case of Germany, Livest. Sci., 157(2-3), 586-596(2013).
13. K. L. Stephen, Life cycle assessment of UK pig production systems: the impact of dietary protein source, The University of Edinburgh, Masters of Philosophy, pp. 1-134(2010).

14. G. Thoma, R. E. Martin, D. Nutter, R. Ulrich, C. Maxewell, G. Frank, National Life Cycle Carbon Footprint Study for Production of US Swine, USA, pp. 1-64(2011).

15. Ministry of Agriculture, Food and Rural Affairs, 2015 Evaluation of Livestock Manure Management Facility and Related Technology(2015).

16. Ministry of Agriculture, Food and Rural Affairs, 2016 Evaluation of Livestock Manure Management Facility and Related Technology(2016).

17. Ministry of Agriculture, Food and Rural Affairs, 2017 Evaluation of Livestock Manure Management Facility and Related Technology(2017).

18. Ministry of Agriculture, Food and Rural Affairs, 2018 Evaluation of Livestock Manure Management Facility and Related Technology(2018).

19. Greenhouse gas Inventory and Research Center, National Greenhouse Gas Inventory Report of Korea(2019).

20. Statistics Korea, Average Temperature of Province and City.

21. Statistics Korea, The Number of Households and the number of Animals by Pig Township/Breeding Size.

22. Ministry of Environment, Results of Recalculation of Basic Units of Livestock Manure Discharge, Notice No. 1999-109(2008).

23. Ministry of Trade, Industry and Energy, the 8th Basic Plan for Power Supply and Demand(2017).

24. France, 2019 Common Reporting Format (CRF) Table(2019).

25. Germany, 2019 Common Reporting Format (CRF) Table (2019).

26. Netherlands, 2019 Common Reporting Format (CRF) Table (2019).

\section{Authors}

\section{Yoosung Park}

Humanitarian Ideal Pathway Co., LTD., Senior Researcher, ORCID(1) 0000-0002-1668-1862

\section{Sung-Mo Yeon}

Humanitarian Ideal Pathway Co., LTD., Chief Executive Officer, ORCID(D) 0000-0001-5357-4655

\section{Kyu-Hyun Park}

Department of Animal Industry Convergence, Kangwon National University, Professor, ORCID [D 0000-0002-6390-5478 